\title{
Environmental modeling in small catchments in the context of climate change: Reda case study
}

Tomasz Walczykiewicz (iD, Ewa Jakusik (iD, Magdalena Skonieczna (iD, Łukasz Woźniak (D)

Institute of Meteorology and Water Management - National Research Institute, Podleśna 61, 01-673 Warszawa, Poland, e-mail: tomasz. walczykiewicz@imgw.pl

ABSTRACT. The BONUS MIRACLE project focuses on understanding the of the impact of climate change on water environments, including it's affects on hydrological regimes and nutrient concentrations. The overall objective of MIRACLE is to initiate a social learning process in collaboration with stakeholders, that can identify new configurations for governance (conceptual, institutional, and practice based) in order to reduce nutrient enrichment and flood risk in the Baltic Sea region. These configurations should be understood as new solutions to protect water resources, ecosystem services and provide win-win solutions. To achieve this environmental modelling of the Reda catchment, Poland, is used as a pilot study for the project. Mathematical models which specified the detailed processes associated with water cycles, including determining interconnections and quantifying variables characteristic to the assessment of the water resource quantity and quality, were found to be useful. Due to the complexity of some models, launching, entering the appropriate data in the correct formats and calibrating the models proved to be challenging. Future developments in the water management sector should concentrate on specific local catchment areas where the application of integrated water resource management principles and the adaptation to climate change are more easily merged with local spatial planning. However, a larger number and higher frequency of measurements would be required.

KEYWORDS: Eutrophication, modeling climate change, nutrient mitigation. 


\section{INTRODUCTION}

As a consequence of increased anthropogenic greenhouse gas emissions, it is hypothesised that the Earth's climate will be warmer in the future (IPCC 2018). This change will mainly affect future generations and the scale of warming will depend on the path of development world chooses. Climate change will affect environmental resources, for example changes in the amount and distribution of precipitation, which will alter the human demands for their ecosystem services, as predicted by climate models.

The European Union has developed a common approach to environmental issues based on the principle of sustainable development, which proposes prudent and economical use of environmental resources to prevent excessive use and degradation which does not lead to a deterioration of the quality of life and limit the development potential of future generations ${ }^{1}$. The current outlook on climate change, as well as the need to take into account a long term perspective, does not change the general objectives of managing environmental resources. Water provides a key ecosystem service, hence the principles of its management are particularly important. This problem is acknowledged globally, resulting in the collaboration of an international community of specialists and politicians through the Integrated Water Resources Management (IWRM) framework. According to Global Water Partnership GWP2, the IRWM "is a process that promotes coordinated management and development of water resources, land and related resources in order to maximize economic and social impact without compromising the balance of key ecosystems" (Hassing et al. 2009).

Climate change has a significant impact on the management of energy and water resources. It can cause violent meteorological and hydrological phenomena as well as changes in the hydrological regime. In the BONUS MIRACLE 3 (Mediating IntegRated ACtions for sustainable ecosystem services in a changing CLimatE) project, analysis of these issues for the small catchment area of the Baltic Sea Region (BSR) was undertaken. The overall objective of MIRACLE was to enact a social learning process that will lead to the identification of new configurations for governance (conceptual, institutional, and practice-based) to reduce nutrient enrichment and flood risk in BSR. One of the pilot catchments for the project was the Reda catchment, Poland. The Reda river catchment was chosen as a pilot study area because it is the largest river that drains water into the Bay of Puck where it has a significant impact on the water quality. The waters and sediments of the Bay of Puck are characterized by an excessive amount of nutrients. The Pomeranian voivodeship spatial development plan (PZPWP 2009) stated that the most important factor degrading coastal waters is excessive discharge of nitrogen and phosphorus compounds and organic substances, which enter Bay of Puck directly from the land or through river runoff, which is increased by limited water exchange with the Baltic Sea.

\section{THE STUDY AREA \\ 2.1. MORPHOLOGY}

The Reda basin is located in four mesoregions (Kondracki 2011). The northern part is located in the Choczewo Heights and the Reda- $Ł e b a$ proglacial valley, while the central and southern parts are situated in the Kashubian Lakeland and the eastern part, where the mouth of the river Reda is located, lies in the Kashubian Coastland mesoregion (Fig. 1).

The basin morphology, elevation and distance from the sea are varied thus local climate is diverse. The highest area is located on the south with a maximum elevation $239.5 \mathrm{~m}$ a.s.l., while the lowest area with elevation about 50 m.a.s.l.s located in the Reda-Łeba floodplain (Fig. 2), where the mouth of the Reda is located.

The Reda river flows roughly from the south to the north in the upper basin, before changing course downstream of Zamostne village to run from west to east. The latitudinal extent of the ba$\sin$ is $0^{\circ} 28^{\prime}$ (about $33 \mathrm{~km}$ ), with the western parts of the basin located furthest from the sea.

According to Woś typology (Woś 1993) which refers to the frequency of weather types, the Reda River basin lies in two climatic regions: Lower Vistula and Eastern Pomerania. The weather in the Lower Vistula region is characterized by either cool air with high humidity and no precipitation, or frosty and very cool conditions with high cloud cover and no precipitation. Alternatively, weather in the Eastern Pomerania region is characterized by cool air temperatures, very cloudy skies and precipitation.

The Baltic Sea - mostly the Gulf of Gdańsk - impact the thermal conditions of the study.

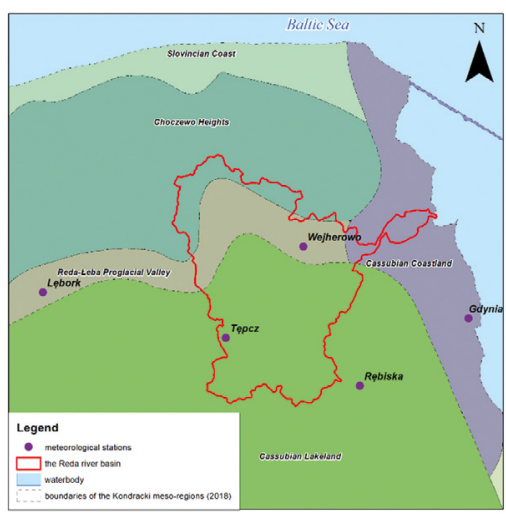

Fig. 1. The Reda basin location within the Kondracki mesoregions (Kondracki 2011)

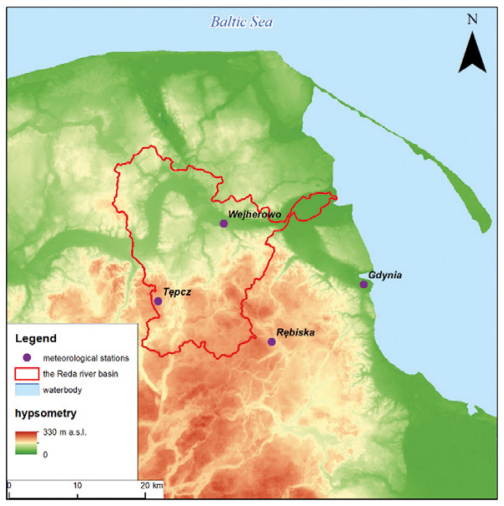

Fig. 2. Hypsometric map of the Reda basin and surroundings; max. basin elevation: $239.5 \mathrm{~m}$ a.s.l.

Thus, remarkable climate characteristics appear, i.e. lengthened spring and winter transition periods, small monthly and diurnal temperature amplitude, lower average temperature during spring than autumn and strong winds with increasing speed in autumn and winter (Staszek, Kistowski 1999; Miętus et al. 2004).

\subsection{LAND USE, HYDROGRAPHY, HYDROLOGY AND WATER QUALITY}

The catchment area of the Reda River is $485 \mathrm{~km}^{2}$. According to the data from the Central Statistical Office, more than 206,000 inhabitants lived in the Reda River basin in 2015. The Reda catchment has an asymmetrical hydrographic network structure. The catchment of the left-bank tributaries is only approximately $1 / 4$ of the entire Reda catchment area. The largest tributary of the Reda is Słuszewska Struga which is the right-bank tributary.

\footnotetext{
https://ec.europa.eu/environment/eussd/

2 https://www.gwp.org/en/GWP-CEE/about/why/what-is-iwrm/

3 BONUS MIRACLE has received funding from BONUS (Art 185), funded jointly by the EU and the national funding institutions Innovation Fund Denmark, Forschungszentrum Jülich Beteiligungsgesellschaft mbH (FZJ-Bt.GmbH), Latvian Ministry of Education and Science, National Centre for Research and Development in Poland, and the Swedish Research Council for Environment, Agricultural Sciences and Spatial Planning (FORMAS).
} 


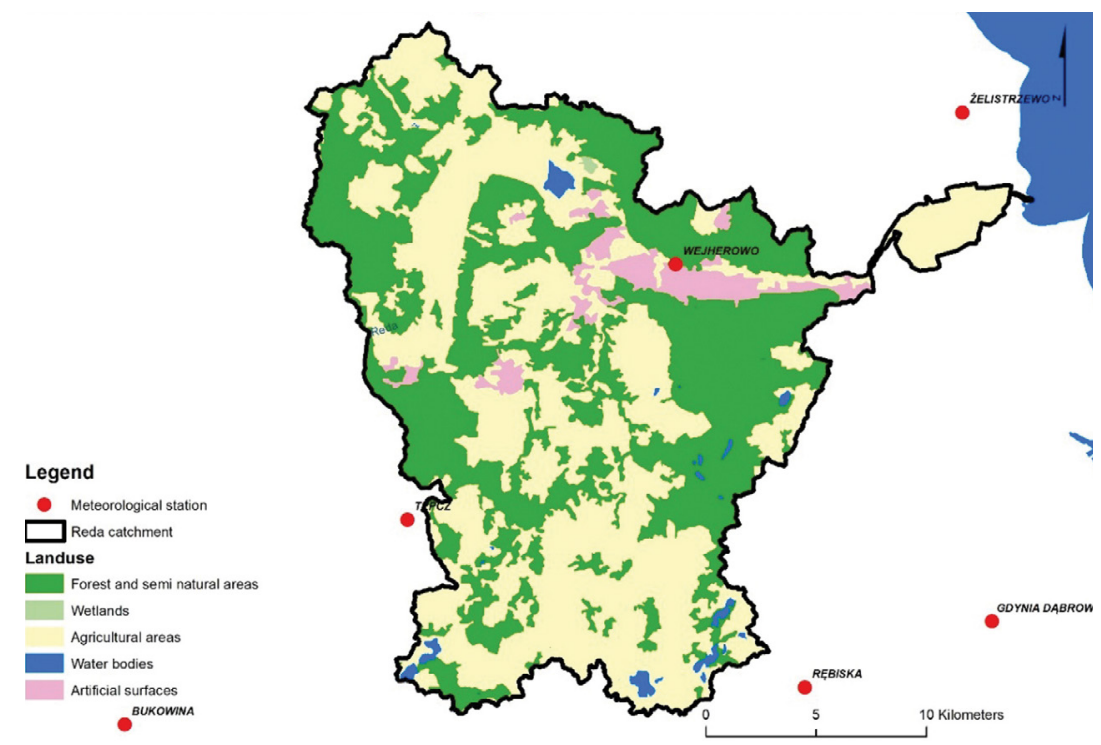

Fig. 3. Land cover in the catchment area of Reda River (based on Corine Land Cover 20064)

Table 1. Weather stations characteristics included in the analysis

\begin{tabular}{|c|c|c|c|c|c|c|}
\hline No. & $\begin{array}{c}\text { Weather } \\
\text { station code }\end{array}$ & Station & $\begin{array}{c}\text { Initial } \\
\text { measurement }\end{array}$ & Altitude (m a.s.l). & Longitude & Latitude \\
\hline 1 & 125 & Lębork & 1966 & 38 & $17^{\circ} 43^{\prime}$ & $54^{\circ} 33^{\prime}$ \\
\hline 2 & 1402 & Gdynia & 1951 & 2 & $18^{\circ} 34^{\prime}$ & $54^{\circ} 31^{\prime}$ \\
\hline 3 & 91429 & Wejherowo & 1951 & 40 & $18^{\circ} 14^{\prime}$ & $54^{\circ} 36^{\prime}$ \\
\hline 4 & 91426 & Tępcz & 1958 & 170 & $18^{\circ} 03^{\prime}$ & $54^{\circ} 30^{\prime}$ \\
\hline 5 & 91425 & Rębiska & 1960 & 17 & $18^{\circ} 20^{\prime}$ & $54^{\circ} 27^{\prime}$ \\
\hline
\end{tabular}

Urbanized parts of the catchment are localized in the downstream part of the river. Agricultural areas are localized close to the Reda River and its tributaries as they are dependent on irrigation (Czarnecka 2005). The land use is dominated by agriculture (arable land, heterogeneous agricultural areas and pastures) and forest, covering $51 \%$ and $44 \%$, respectively. Agricultural areas dominate in both the upper areas of the catchment and around the estuary. Approximately $4 \%$ of the catchment is covered by artificial surfaces, while wetlands and water bodies cover an insignificant area of the catchment (Fig. 3).

One of the most significant risks in the Reda catchment is flooding caused by heavy rains, snowmelt and local water jams In the coastal zone of the Gulf of Puck, flood risk is increased by storm surges caused by strong winds. An additional problem is the accumulation or retention of water in urbanized areas following heavy rains, particularly in the cities of Reda and Wejherowo. Coastal areas at risk of storm surges, as well as lower parts of the Reda River are protected by the levees. On the other hand, the most urbanized Reda River section from Wejherowo to Reda City is not embanked. Suburbanization and chaotic development of the in- habited areas including intensive development of housing (e.g. Moście Błota in the Kosakowo commune) alongside existing settlements, further raise the flood risk.

The main flow characteristics of the Reda River at the cross section in Wejherowo are following:

- maximum observed flow (WWQ) - $20.9 \mathrm{~m}^{3} \mathrm{~s}^{-1}$;

- maximum average annual flow (WSQ) $13.8 \mathrm{~m}^{3} \mathrm{~s}^{-1}$

- average of mean annual flow (SSQ) $-4.35 \mathrm{~m}^{3} \mathrm{~s}^{-1}$;

- average of annual minimum flows (SNQ) $1.67 \mathrm{~m}^{3} \mathrm{~s}^{-1}$;

- minimum observed flow (NNQ) $-0.67 \mathrm{~m}^{3} \mathrm{~s}^{-1}$.

There are two key point sources for nutrients loading in the Reda catchments: municipal sewage treatment plants and fish ponds.

Data for discharge and nutrient concentrations were obtained from 26 different point sources. Analysis of this data showed that the majority of municipal wastewater generated in the Reda catchment is discharged outside the catchment to the sewage treatment plant "Dębogórze" near the city of Rumia (located within the Kosakowo municipality). This sewage diversion includes parts of Reda, Wejherowo and Szemud, which are connected to the sewer system. Information on rural sewage discharges in the Reda catchment were estimated based on data on the population density outside the main urban areas.

Consumption of mineral fertilizers in terms of pure ingredient per 1 hectare (ha) of agricultural land in Pomeranian Voivodeship equals $74.8 \mathrm{~kg} \mathrm{~N} \mathrm{ha}^{-1}$ and $18.3 \mathrm{~kg} \mathrm{P} \mathrm{ha}^{-1}$ in 2015. Compared to the consumption of mineral fertilizers in 2010 , this was a decrease of $-2.7 \mathrm{~kg} \mathrm{~N}$ $\mathrm{ha}^{-1}$ and $6.6 \mathrm{~kg} \mathrm{P} \mathrm{ha}^{-1}$, respectively. The highest consumption of mineral $\mathrm{N}$ and $\mathrm{P}$ was in the urban area of Wejherowo and Luzino commune. The highest consumption of mineral $\mathrm{N}$ per ha of agricultural land in the Reda catchment was in the Luzino commune $\left(-67 \mathrm{~kg} \mathrm{~N} \mathrm{ha}^{-1}\right)$. However, this rate is still $-13 \%$ lower than the average consumption of fertilizers in the Pomeranian Voivodeship. Similarly, consumption of phosphate fertilizers in the Reda catchment was highest in the Luzino commune, with an avergae consumption lower than in the Pomeranian Voivodeship.

There is a large variation in the total area of agricultural land within communes in the Reda catchment. The analysis shows that most farms in the Reda catchment are of small (1-5 ha) or medium (5-10 ha) size. Data from the Agency for Restructuring and Modernisation of Agriculture (ARMA 2016) suggests that the average size of farms in the Pomeranian Voivodeship was 19.02 ha in 2015 .

In order to limit the loading of nutrients which affect the Baltic Sea, it is necessary for all farmers in Reda catchment to cooperate. This could be challenging considering the large number of small- and medium-size farms, however the overall consumption of mineral fertilizers in the Reda catchment is considered to be quite small. Results of water quality measurements at the station Mrzezino (north-east of Reda) for 2014 are as follows:

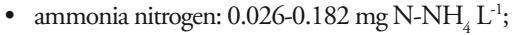

- nitrate nitrogen: 0.33-1.11 mg N-NO $\mathrm{NO}_{3}^{-1}$;

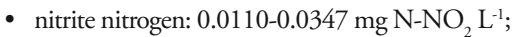

- phosphates: 0.112-0.265 mg $\mathrm{PO}_{4} \mathrm{~L}^{1}$.

\subsection{CLIMATIC}

\section{CHARACTERISTICS}

\subsubsection{METHODOLOGY}

Climate analysis was based on data from five weather stations: Lębork (synoptic station), Gdynia (climate station), Wejherowo, Rębiska and Tępcz (precipitation station). Only Wejherowo and Tęp$\mathrm{CZ}$ are located within the Reda basin. The other 

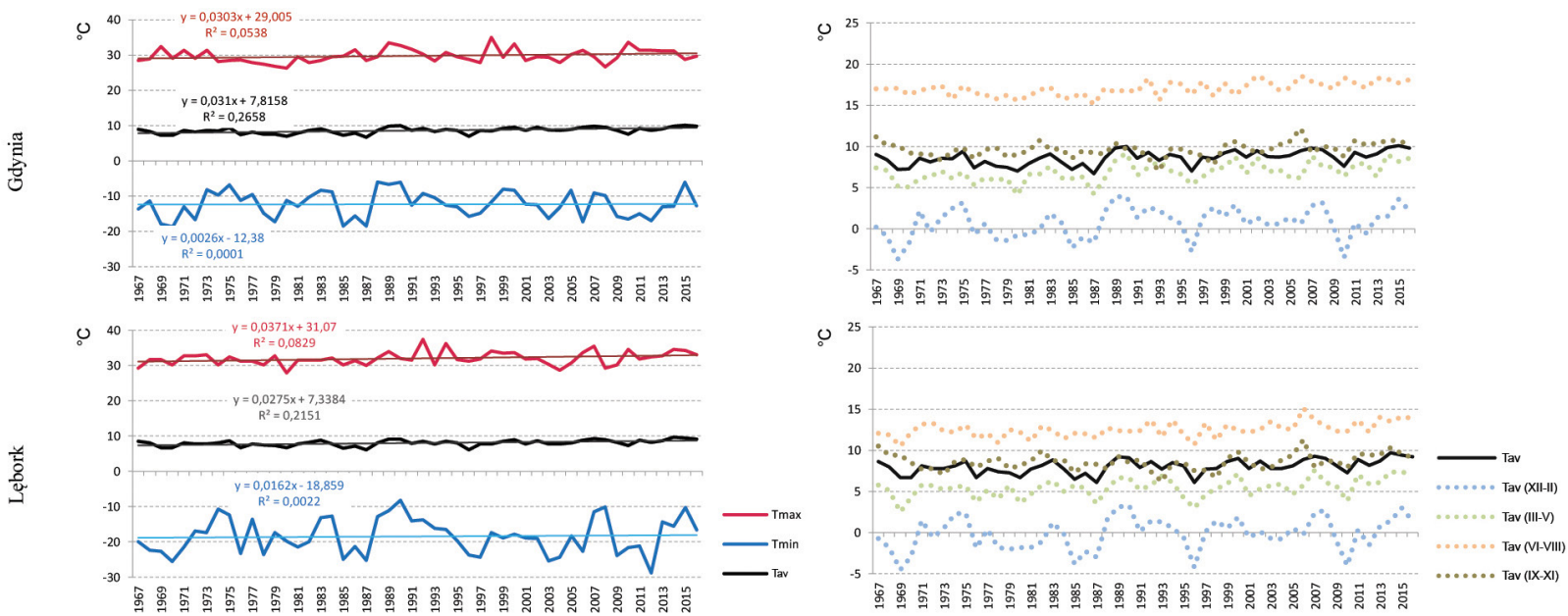

Fig. 4. Variability of annual and seasonal maximum, minimum and average temperatures at the Gdynia and Lębork weather stations, between 1967 and 2016

stations, including Gdynia (14 km east), Rębiska ( $2 \mathrm{~km}$ south east) and Lębork (17.5 km west), are at variable distances from the catchment (Fig. 2).

Five additional precipitation stations are located within $11 \mathrm{~km}$ of the basin. These stations were not used in the analysis as precipitation has a primarily local influence, and so interpolation could result in a misleading characterization of precipitation in the basin area (Szalińska, Otop 2012). In the authors' opinion, the spatial distribution of the weather stations analyzed in this study provides suitable coverage of precipitation data in the catchment, with suitable representation of basin landforms. Although Gdynia station is located around $14 \mathrm{~km}$ from the basin, it was included in the analysis as it best reflects pluvial conditions in the Reda estuary.

Variability of the temperature and precipitation over the Reda basin have been studied using the data of five stations. The analysis was conducted with verified daily data for the 50-years period from 1967 to 2016 inclusive, using temperature data from the Gdynia and Lębork weather stations and precipitation data from the Gdynia, Wejherowo, Rębiska and Tępcz weather stations.

The time period typically used to characterize a climate system is 30 years. Currently, as a result of rapid changes in the natural environment, statistical analyses of various climate elements increasingly use average values from 30 or 50 years. Therefore, taking into account the characteristic meteorological conditions, expressed by average and extreme values of meteorological elements in the catchment of the Reda River, we assessed the shorter measuring period of 2004-2014 and the longer period of 1967-2016, to emphasize the tendency of these changes.

Linear regression equations (Excel function LINEST) were used to determine the direction and value of the tendency of changes in the considered periods. The statistical significance of this trend was defined by a significance level of $1-\alpha=0.95$.

\subsubsection{TEMPERATURE}

Annual mean temperature at the Gdynia station in period $1967-2016$ varied by $3.4^{\circ} \mathrm{C}$. The coldest year was 1987 with an annual average temperature of $6.7^{\circ} \mathrm{C}$, while 2015 and 1990 were the hottest years with annual average temperatures of $10.1^{\circ} \mathrm{C}$ and $10.0^{\circ} \mathrm{C}$, respectively. Annual average temperature at the Lębork station varied by $3.6^{\circ} \mathrm{C}$. The coldest years were 1987 and 1996 with an average of $6.1^{\circ} \mathrm{C}$, while 2014 was the hottest year with an average temperature of $9.7^{\circ} \mathrm{C}$ (Fig. 4).

The daily maximum temperature at Gdynia occurred on the 21 July 1988 with temperature of $35.0^{\circ} \mathrm{C}$. The $95^{\text {th }}$ percentile of Gdynia daily maximum temperature, based on the 50 -year period 1967 to 2016 inclusive, was $25.3^{\circ} \mathrm{C}$ in 2010 . A daily average 95th percentile value based on the period $1967-2016$ was $23^{\circ} \mathrm{C}$. The highest temperature of the period was $37.4^{\circ} \mathrm{C}$ at Lębork, occurring on 10 September 1992 . The $95^{\text {th }}$ percentile of Lębork daily maximum temperature based on period $1967-2016$ was $28.1^{\circ} \mathrm{C}$, also occuring in 2010 . Its daily annual average was $26.0^{\circ} \mathrm{C}$.

July and August were the hottest months, with the exception of 2000, when June was the hottest month at both Gdynia and Lębork (Fig. 5).

The daily minimum temperature at Gdynia of $-18.7^{\circ} \mathrm{C}$ was recorded on the 2nd Febru- ary 1970. The 5th percentile of Gdynia daily minimum temperature occurred in 1987 with the value of $-10.4^{\circ} \mathrm{C}$. A daily average value in the period was $-5.0^{\circ} \mathrm{C}$. At Lębork, daily minimum of $-28.8^{\circ} \mathrm{C}$ was recorded on the 6 th of February 2012. The 5th percentile of Lębork daily minimum temperature also occurred in 1987 , with the value of $-16.3^{\circ} \mathrm{C}$. A daily average value in the period was $-5.5^{\circ} \mathrm{C}$.

January and February were the coldest months at Gdynia and Lębork (Fig. 5).

Seasonal average temperatures for months December-February at Gdynia and Lębork were $0.7^{\circ} \mathrm{C}$ and $-0.2^{\circ} \mathrm{C}$, respectively; for MarchMay, $6.8^{\circ} \mathrm{C}$ and $5.5^{\circ} \mathrm{C}$; June-August, $17.0^{\circ} \mathrm{C}$ and $12.5^{\circ} \mathrm{C}$; and September-November, $9.6^{\circ} \mathrm{C}$ and $8.6^{\circ} \mathrm{C}$. The biggest amplitude in temperature variability was recorded during winter months. In the period 1967-2016, monthly amplitude in winter reached $7.6^{\circ} \mathrm{C}$ at Gdynia and $7.8^{\circ} \mathrm{C}$ at Lębork. In spring, summer, and autumn months, the amplitude reached value $5.1^{\circ} \mathrm{C}$, $3.5^{\circ} \mathrm{C}$ and $5.2^{\circ} \mathrm{C}$ at Gdynia; and $5.1^{\circ} \mathrm{C}, 4.6^{\circ} \mathrm{C}$ and $5.1^{\circ} \mathrm{C}$ at Lębork, respectively (Fig. 5).

\subsubsection{PRECIPITATION}

Annual average rainfall at Wejherowo, Tępcz, Rębiska and Gdynia stations in the period 19672016 varied between $156.7 \mathrm{~mm}$ and $1,199.2 \mathrm{~mm}$. The highest annual average value was recorded at $804.6 \mathrm{~mm}$ at the Wejherowo station. At Tępcz, Rębiska and Gdynia stations the highest annual average values were $726.5,636.6$ and $572.7 \mathrm{~mm}$, respectively.

The highest annual precipitation occurred in 1980 at Wejherowo station $(1,199.2 \mathrm{~mm})$, 2007 at Tępcz station (1,039.2 mm), 1970 

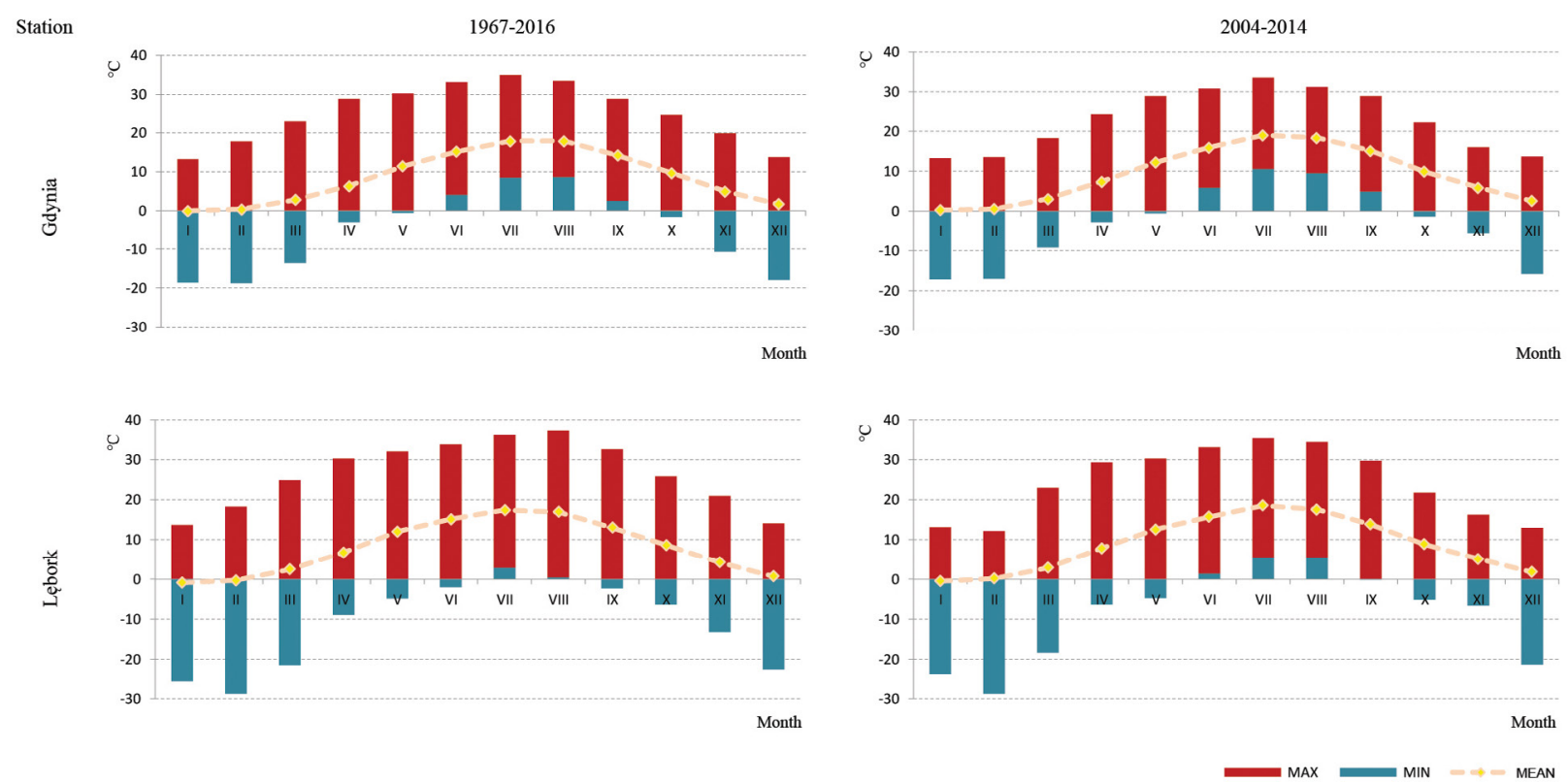

Fig. 5. Variability of monthly maximum, minimum and mean temperature (1967-2016) and (2004-2014) at Gdynia and Lębork
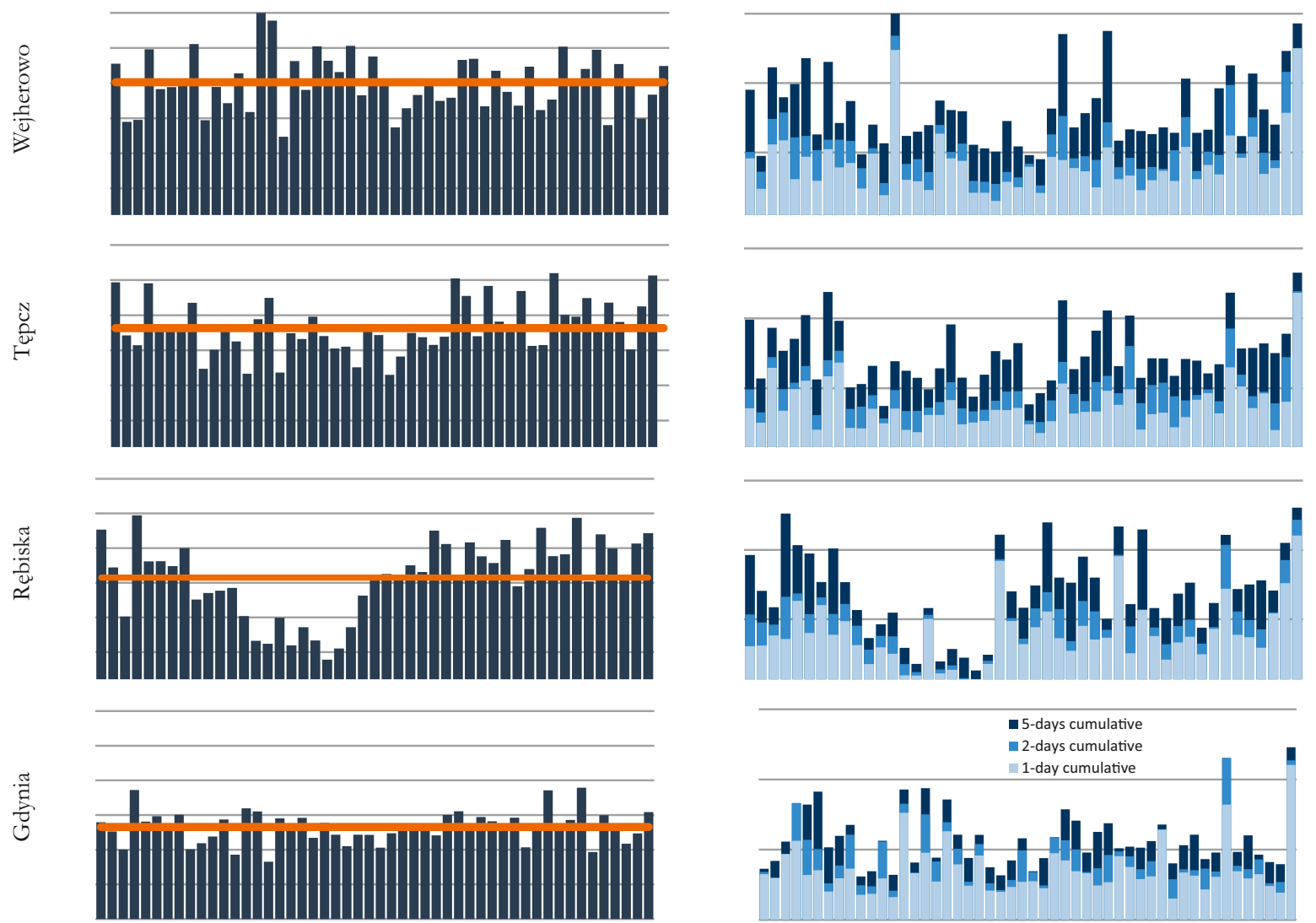
at Rębiska station $(988.6 \mathrm{~mm})$ and in 2010 at Gdynia station $(758.2 \mathrm{~mm})$. The lowest annual value was recorded at Rębiska station in 1989 (156.7 mm), Gdynia station in 1982 (330.3 mm), Tępcz station in 1992 (460.4 mm), and at Wejherowo station in $1982(494.5 \mathrm{~mm})$. Cumulative rainfall maximum for 1,2 and 5 days were recorded as: $125 \mathrm{~mm}$ (2016), 134.2 (1980) and $159.1(1980)$ at Wejherowo station, respectively; $118.3 \mathrm{~mm}$ (2016), $119.5 \mathrm{~mm}$ (2016) and $132.7 \mathrm{~mm}$ (2016) at Tępczstation; $110.4 \mathrm{~mm}$ (2016), $121.7 \mathrm{~mm} \mathrm{(2016)} \mathrm{and} 130.5 \mathrm{~mm}$ (2016) at Rębiska station; and $110.4 \mathrm{~mm}$ (2016), $115.2 \mathrm{~mm} \mathrm{(2010)}$ and $123.0 \mathrm{~mm}$ (2016) at Gdynia station (Fig. 6).

In the period 1967-2016 the highest monthly rainfall was generally recorded in June and the lowest in April (with an exception at Gdynia station, where minimum values were recorded in February). In June the monthly average rainfall was $90.8 \mathrm{~mm}$ at Wejherowo, $83.8 \mathrm{~mm}$ at Tępcz, $77.4 \mathrm{~mm}$ at Rębiska and $69.5 \mathrm{~mm}$ at Gdynia. In April, monthly average rainfall was $42.4 \mathrm{~mm}$ at Wejherowo, $37.0 \mathrm{~mm}$ at Tępcz, and $34.6 \mathrm{~mm}$ at Rębiska. At Gdynia, the lowest monthly average rainfall was in February, $21.3 \mathrm{~mm}$.

The monthly average rainfall was higher between 2004-2014 than between 1967-2016, with differences of $10.9 \mathrm{~mm}$ at Rębiska, $4.5 \mathrm{~mm}$ at Tępcz, $1.7 \mathrm{~mm}$ at Gdynia and $0.6 \mathrm{~mm}$ at Wejherowo.

\section{MODELED IMPACTS OF CLIMATE CHANGE}

Assessing the impact of future change is an essential component of modeling the impact of measures selected within the MIRACLE project. To allow for a long-term planning and management on a national level, a 30-year model period centered around 2030 (2016 to 2045) was chosen.

The changes were compared to the baseline simulation for a recent 10 year period (2004 to 2014). In the MIRACLE project, climate change impact assessments were included in the modeling for RCP8.5 projections for two regional climate model datasets: WRF-IPSL-CM5A-MR (WRF) ${ }^{5}$ and RCA4CanESM2 (RCA) ${ }^{6}$ (Bartosova, Capell 2017). Two regional climate model datasets were used to show the highest increases in precipitation (WRF, RCA) and temperature (WRF, RCA) until 2030 and the effects on water and nutrient flows in the case study area. Two sub-basins related to the Reda catchment

Table 2. Comparison of monthly average temperatures in sub-basins 6351 and 6352 between model WRF/RCA predictions for scenario RCP 8.5 (2016-2045) and measurement data from Lębork/Gdynia stations (2004-2014) [ $\left.{ }^{\circ} \mathrm{C}\right]$

\begin{tabular}{|c|c|c|c|c|c|c|c|c|}
\hline \multirow[b]{2}{*}{ Month } & \multicolumn{8}{|c|}{ (2004-2014) and (2016-2045) difference } \\
\hline & 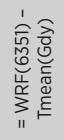 & 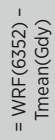 & 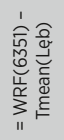 & 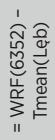 & 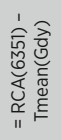 & 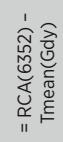 & 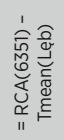 & 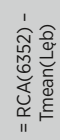 \\
\hline Jan & -0.1 & -0.1 & 0.75 & 0.78 & 1.03 & 1.03 & 0.21 & 0.21 \\
\hline Feb & 0.51 & 0.7 & 0.96 & 1.16 & 0.04 & 0.01 & -0.4 & -0.43 \\
\hline Mar & 0.47 & 0.9 & 0.71 & 1.18 & 0.29 & -0.2 & 0.05 & -0.45 \\
\hline Apr & 0.27 & 1.1 & -0.27 & 0.54 & 0.21 & -0.54 & 0.75 & -0.01 \\
\hline May & 0.43 & 1.3 & 0.17 & 1.06 & 0.24 & -0.66 & 0.51 & -0.39 \\
\hline Jun & -0.38 & 0.5 & -0.12 & 0.75 & 0.3 & -0.57 & 0.03 & -0.83 \\
\hline Jul & -0.75 & 0 & -0.33 & 0.45 & 1.08 & 0.38 & 0.66 & -0.04 \\
\hline Aug & -0.1 & 0.6 & 0.81 & 1.52 & 0.26 & -0.35 & -0.66 & -1.27 \\
\hline Sep & -0.49 & -0.1 & 0.81 & 1.16 & 1.02 & 0.52 & -0.27 & -0.77 \\
\hline Oct & -0.62 & -0.3 & 0.48 & 0.82 & 1.7 & 1.33 & 0.6 & 0.23 \\
\hline Nov & -2.03 & -1.8 & -1.28 & -1.04 & 1.39 & 1.18 & 0.65 & 0.44 \\
\hline Dec & -1.48 & -1.4 & -0.68 & -0.6 & 0.8 & 0.74 & 0 & -0.06 \\
\hline average & -0.36 & 0.12 & 0.17 & 0.65 & 0.7 & 0.24 & 0.18 & -0.28 \\
\hline
\end{tabular}

Imean(Gdy) - monthly average temperature $\left[{ }^{\circ} \mathrm{C}\right]$ in the period 2004-2014 at Gdynia; obtained from daily measurement data; Tmean (Leb) - monthly average temperature $\left[{ }^{\circ} \mathrm{C}\right]$ in the period 2004-2014 at Lebork; obtained from daily measurement data; WRF/RCA - monthly average temperature $\left[{ }^{\circ} \mathrm{C}\right]$ in the period 2016-2045 from models WRF and RCA; obtained from daily scenario data

(6351 and 6352) were analyzed. The numerical designation of the sub-basins is defined by the numeration of the nearest grid of the climate model.

Climate represents only one aspect of changes we can expect to occur by the 2050s. Land use, agriculture, population, lifestyle, legislation, and economic development are also important drivers that change over time and can significantly affect generation and transport of nutrients to Baltic Sea. Thus, the possible changes modeled with HYPE (HYdrological Predictions for the Environment; see Section 4) that could occur by the 2050 s can be altered by two aspects: changes in the climate forcing data and changes in socioeconomic variables.

\subsection{THERMAL CONDITION}

According to the WRF model, monthly average temperatures within sub-basin 6531 are predicted to decrease by $-0.36^{\circ} \mathrm{C}$ for the period 2016-2045 (Table 2), compared to the average temperature at Gdynia for period 2004-2014. The model shows that the monthly temperature will increase by $-0.42^{\circ} \mathrm{C}$ in February-May, but decrease by $--0.74^{\circ} \mathrm{C}$ in July-January. Within sub-basin 6532 , monthly average temperature is predicted to increase by $0.12^{\circ} \mathrm{C}(\mathrm{Ta}-$ ble 2) in relation to measured values at Gdynia between 2004-2014. The monthly average temperature in July is predicted to remain unchanged. According to the model, the tem- perature in the basin will increase in by $0.85^{\circ} \mathrm{C}$ in February-June and August, whereas it will decrease in by $0.74^{\circ} \mathrm{C}$ in September-January, when compared to Gdynia observations.

In relation to the data from Lębork station, according to the projection, monthly average temperature will increase by $0.17^{\circ} \mathrm{C}$ in sub-ba$\sin 6531$. Temperature increases of $-0.75^{\circ} \mathrm{C}$ are projected in January-March and August-October, with decreases of $-0.42^{\circ} \mathrm{C}$ in November and December. In the model, it is assumed that the sub-basin 6532 monthly average temperature will be higher by $-0.65^{\circ} \mathrm{C}$ in the period 2016-2045 (Table 2). Model predictions show that January-October monthly average temperature will rise by $-0.94^{\circ} \mathrm{C}$, whereas temperatures in November and December will decrease by $--0.82^{\circ} \mathrm{C}$, when compared to empirical data from the Lębork station in period 2004-2014.

According to the RCA model, it is predicted that in sub-basin 6531 and 6532 average temperatures will increase by $-0.70^{\circ} \mathrm{C}$ and $0.24^{\circ} \mathrm{C}$, respectively, in period 2016-2045, when compared to Gdynia empirical data. Compared to Lębork station measurements, average temperatures in sub-ba$\sin 6531$ are predicted to increase by $0.18^{\circ} \mathrm{C}$, but decrease in sub-basin 6532. In the RCA model, it is assumed that monthly average temperature in sub-basin 6532 in September-February and July will increase by $-0.74^{\circ} \mathrm{C}$ and decrease in March-June and August by $--0.46^{\circ} \mathrm{C}$, compared to the long-term average at Gdynia.

\footnotetext{
5 https://euro-cordex.net/

${ }^{6}$ https://www.smhi.se/polopoly_fs/1.90273!/Menu/general/extGroup/attachmentColHold/mainCol1/file/RMK_116.pdf
} 
Table 3. Comparison of monthly precipitation in sub-basins 6351 and 6352 between model WRF/RCA predictions for scenario RCP 8.5 (2016-2045) and measurement data from Wejherowo/Tępcz stations in the period 2004-2014 [mm]

\begin{tabular}{|c|c|c|c|c|c|c|c|c|}
\hline \multirow[b]{2}{*}{ Month } & \multicolumn{8}{|c|}{ (2004-2014) and (2016-2045) difference } \\
\hline & 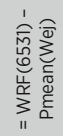 & 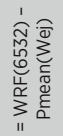 & 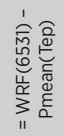 & 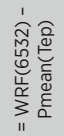 & 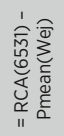 & 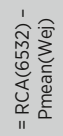 & 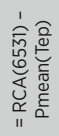 & 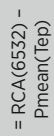 \\
\hline Jan & 11.9 & -17.3 & 24.1 & -5 & 15.2 & -8.3 & 27.5 & 4 \\
\hline Feb & 18.9 & -3.4 & 30.8 & 8.5 & 25 & 0.1 & 36.9 & 12 \\
\hline Mar & 21.8 & -8.5 & 35 & 4.8 & 20.3 & -7.6 & 33.5 & 5.6 \\
\hline Apr & 10.2 & 7.3 & 12.9 & 10.1 & 14.8 & 11.8 & 17.6 & 14.6 \\
\hline May & -6.8 & -24 & -1.5 & -18.7 & 8.7 & -5.1 & 14 & 0.2 \\
\hline Jun & 8.3 & -2.2 & 13.4 & 2.9 & 11.3 & -2 & 16.4 & 3.1 \\
\hline Jul & -24.3 & -38.4 & -6.7 & -20.8 & -13.9 & -22.8 & 3.6 & -5.3 \\
\hline Aug & -44.2 & -53.3 & -28.4 & -37.5 & -15.9 & -20.4 & -0.1 & -4.6 \\
\hline Sep & -41.7 & -43.8 & -43.9 & -45.9 & -16.7 & -27.8 & -18.8 & -30 \\
\hline Oct & 8.5 & -4.1 & 8.5 & -4.1 & 19.4 & 8.9 & 19.3 & 8.9 \\
\hline Nov & -12.9 & -21.7 & -6.7 & -15.5 & -13.4 & -21.9 & -7.2 & -15.7 \\
\hline Dec & 22 & -5.9 & 29.3 & 1.4 & 12.9 & -8.4 & 20.2 & -1.2 \\
\hline average & -2.4 & -17.9 & 5.6 & -10 & 5.6 & -8.6 & 13.6 & -0.7 \\
\hline
\end{tabular}

Pmean(Wej) - monthly average precipitation [mm ] in the period 2004-2014 at Wejherowo; obtained from daily measurement data; Pmean(Tep) - monthly average precipitation [mm] in the period 2004-2014 at Tępcz; obtained from daily measurement data; WRF/RCA - monthly average precipitation [mm] in the period 2016-2045, obtained from WRF, RCA models; obtained from daily scenario data

Compared with the Lębork station data, it is predicted that temperatures in December in sub-basin 6531 will remain unchanged, whereas in February, Augustand September temperatureswill decreaseby - $-0.46^{\circ} \mathrm{C}$, but increase in the other months by $0.44^{\circ} \mathrm{C}$

\subsection{PLUVIAL CONDITION}

WRF model projections in 2016-2045 shows that monthly average precipitation will decrease by - $-0.1 \mathrm{~mm}$ and $-0.5 \mathrm{~mm}$ in sub-basins 6531 and 6532, respectively, when compared to Wejherowo station measured data for 20042014. A decrease of $-0.3 \mathrm{~mm}$ is also predicted in sub-basin 6532 compared to Tępcz station observations. In the WRF model, monthly average precipitation is assumed to increase by approximately $0.2 \mathrm{~mm}$ in only sub-basin 6531, compared to Tępcz measurements in 2004-2014.

In the RCA model it is predicted that monthly average precipitation will increase by $-5.6 \mathrm{~mm}$ and $13.6 \mathrm{~mm}$ in sub-basin 6531 compared to Wejherowo station and Tępcz station measured data for 2004-2014, respectively. In sub-basin 6532, it is predicted that monthly precipitation will decrease by $-8.6 \mathrm{~mm}$ and $-0.7 \mathrm{~mm}$ compared to Wejherowo and Tępcz stations, respectively.

\section{DISCHARGE \\ AND NUTRIENTS MODELING}

For discharge and nutrients modeling the HYPE model (Hydrological Predictions for the Environment) was used. HYPE is an open source integrated rainfall-runoff and nutrient transfer model developed and maintained by the Swedish Meteorological and Hydrological Institute (SMHI).

To run the HYPE model for runoff and nitrogen simulation, several types of spatial data (including Digital Elevation Model, stream network, land use and soil type), time series data and statistical data were required. These datasets were gathered during the initial phase of the project and were improved during workshops. For the time series data, climate forcing data for daily precipitation and daily mean air temperature for each sub-basin were required. Statistical data required included initial nutrient pools in the soil, agricultural practices (i.e., manure and chemical fertilizer applications, crop husbandry, timing and amount of fertilization, sowing and harvesting), wet and dry atmospheric depositions of nutrients, and nutrient concentrations and outflow volumes of point sources from rural household, industrial and waste water treatment plants.

For model calibration and validation, discharge and in-stream nutrient concentration (inorganic nitrogen (IN), organic nitrogen $(\mathrm{ON})$, total nitrogen $(\mathrm{TN})$, soluble reactive phosphorus (SP), particulate phosphorus (PP) and total phosphorus (TP)) observed from one or several locations of the stream were used. Observations of internal hydrological variables (groundwater level, evapotranspiration and soil moisture) were also used for model parameter calibration and evaluation of model performance.
There are a relatively large number of hydrological and nitrogen process parameters required to be specified in the application of HYPE model (Lindström et al. 2010). Model parameters are sorted into general parameters, land-use dependent parameters and soil-type dependent parameters. For runoff simulation, most parameters reflect water holding characteristics, evapotranspiration rates, flow paths and recession rates. Considering nitrogen simulation, the model parameters describe processes of nitrogen transformations and sinks.

The baseline period includes effects of measures resulting from The National Programme for Construction of Urban Wastewater Treatment Plants (RBMP 2016) and The River basin management plans (2016-2021) (RBMP 2016), including measured which are currently implemented or that have been agreed upon in previous plans. The results of the modeling were compared with the baseline period of 2006-2014.

\subsection{DISCHARGE MODELLING}

For the daily discharge modeling in HYPE, two periods were selected from 2004-2014; a calibration dataset from 2004-2005 and a validation dataset from 2006-2014. Figure 7 shows the model performance results from validations of discharge in sub-basin 7 (the location of the gauging station in Wejherowo City) in the Reda catchment. The elements of the system are the Reda channel, waterway, and a weir which dams the water for a cement plant. Locations of sub-basins and gauging stations is shown on Figure 7.

Modelled discharge dynamics within the Reda basin were evaluated at the gauging station (sub-basin 7; Fig. 7). Generally, hydrodynamics in the Reda basin are characterised by rapid flow variations, higher discharges during the winter months, and low flow periods during summer. Total outflow of freshwater to Baltic Sea averaged over the simulated 30-year periods is presented in Figure 8.

\subsection{NUTRIENT MODELING}

In the case of the Reda catchment, difficulties in nutrient modeling were caused by an inconsistency between the location for flow measurements and those for water quality measurements. The longest time-series of observations for water quality is from the monitoring point called Reda Mrzezino, located below the mouth of the River Cedron, but this station has no flow monitoring. In contrast, the water gauge for calibrating the model in terms of discharge 
is located above the mouth of the River Cedron. As a result, some assumptions had to be made to use the results of quality measurements above the mouth of the River Cedron. Additional quality datasets have been obtained for sub-basin 2 (for 2011 only) and sub-basin 10 (2010 to 2014).

Projected climate change in WRF climate model predicted reduced daily concentration of $\mathrm{N}$ and $\mathrm{P}$ in the Reda catchment on average by $4.0 \%$ and $7.7 \%$, respectively, compared to the baseline period (Fig. 9).

Projected climate change in RCA climate model predicted reduced daily concentration of $\mathrm{N}$ and $\mathrm{P}$ in the Reda catchment on average by $9.2 \%$ and $12.8 \%$, respectively, compared to the baseline period (Fig. 10).

\section{RESULTS}

Results of the MIRACLE project delivered important information for present and future integrated water management. In comparison with the years 1967-2016, the average monthly air temperature during 2004-2014 was higher by 0.2 (October) to $1.1^{\circ} \mathrm{C}$ (July) in Lębork and Gdynia. On the other hand, the average annual precipitation for the period 2004-2014 was higher by $10.9 \mathrm{~mm}$ in Rębiska, $4.5 \mathrm{~mm}$ in Tępcz and $1.7 \mathrm{~mm}$ in Gdynia, and lower by $0.6 \mathrm{~mm}$ in Wejherowo.

For sub-basin 6531, the results of the RCA model according to the RCP8.5 scenario predict that in the period 2016-2045, the average monthly air temperature will change from $-0.1^{\circ} \mathrm{C}$ in January to $18.4^{\circ} \mathrm{C}$ in July. On the other hand, using the WRF model for the same sub-basin and climate scenario, the monthly average air temperature is predicted to range from $-0.1^{\circ} \mathrm{C}$ in January to $18.0^{\circ} \mathrm{C}$ in July and August. For sub-basin 6532, the results of the RCA model according to the RCP8.5 scenario predict that in 20162045 the average monthly air temperature will vary from $-0.1^{\circ} \mathrm{C}$ in January to $19.1^{\circ} \mathrm{C}$ in July, while the WRF model predicts a change of $-0.1^{\circ} \mathrm{C}$ in January to $18.9^{\circ} \mathrm{C}$ in July. The RCA model forecasts higher monthly average temperatures for sub-basins 6531 and 6532 from June to October, December and February. Moreover, in the period 2016-2045, an increase of annual precipitation in sub-basin 6531 is predicted for RCP8.5 by both models. The RCA model forecasts higher monthly precipitation totals for sub-basins 6531 and 6532 in February, March, June, July, September, October and December, compared to the WRF model for the RCP8.5 scenario.

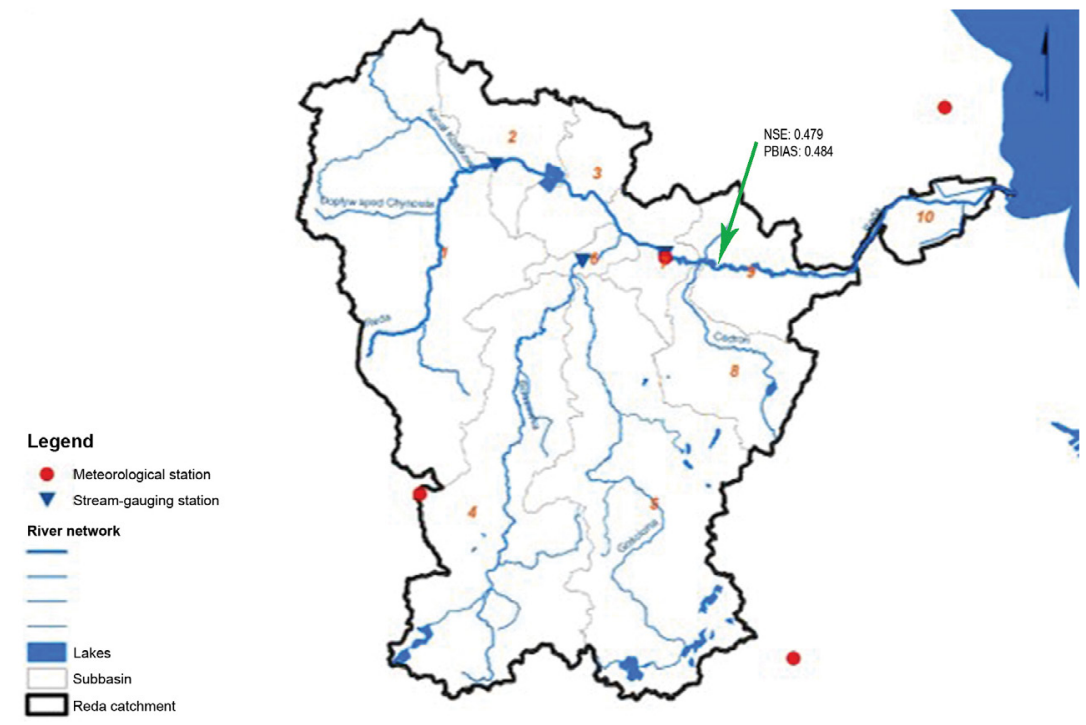

Fig. 7. Location of discharge gauging station in Reda River with HYPE model performance for baseline period 2006-2014 (NSE, PBIAS)

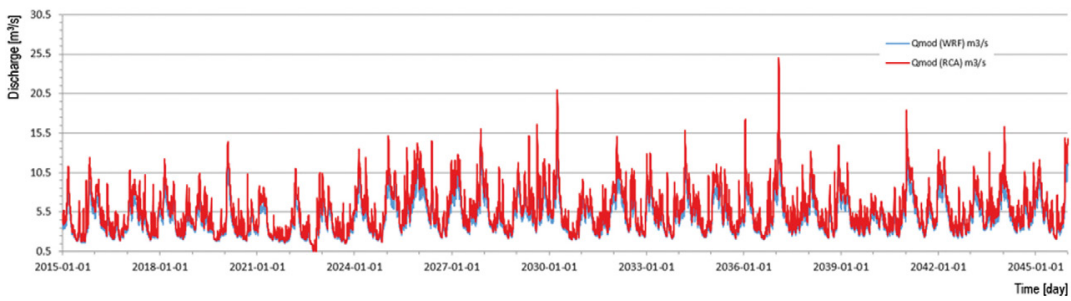

Fig. 8. Modelled discharge dynamics at the gauging station in the Reda River

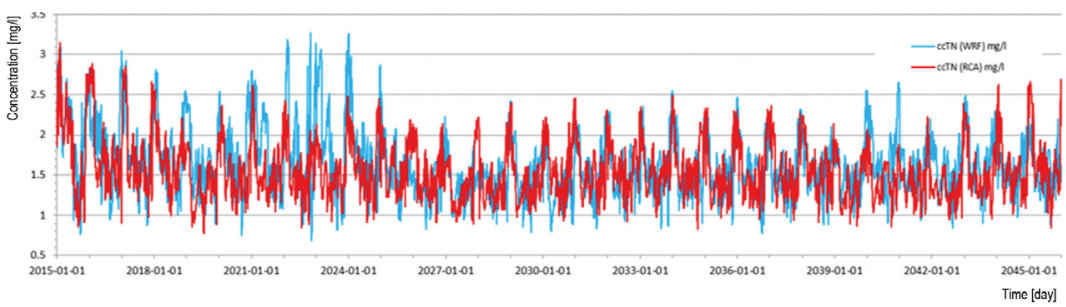

Fig. 9. Simulation of the daily total-N concentrations $(\mathrm{mg} / \mathrm{L})$ at the outlet of the Reda catchment for 2015-2045, using the WRF (blue) and RCA (red) models

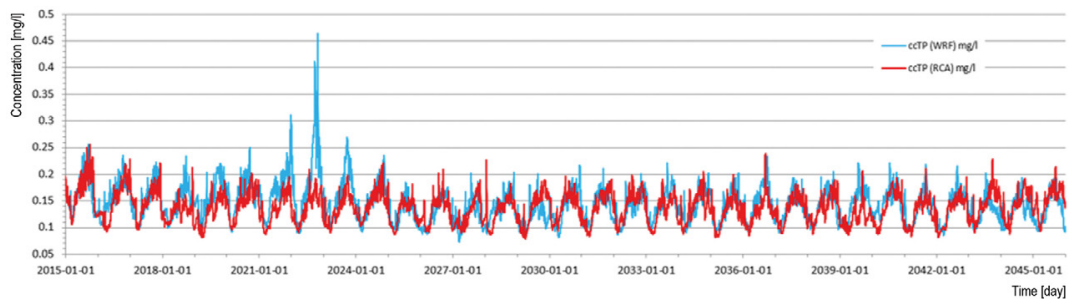

Fig. 10. Simulation of the daily total-P (mg/L) at the outlet of the Reda catchment for 2015-2045, using WRF (blue) and RCA (red) models

Results of modeling indicate a moderate increase of outflow from Reda catchment, averaging $14 \%$ and $18 \%$, respectively for WRF and RCA regional climate models compared to the baseline period. However, the reliability of the model should be considered. In the case of the Reda catchment, difficulties in nutri- ent modeling were caused by an inconsistency between the location of water flow stations and those for water quality measurements. Projected climate change both in the WRF and RCA regional climate models predict a reduced concentration of $\mathrm{N}$ and $\mathrm{P}$ in the Reda catchment. 


\section{CONCLUSIONS}

This study confirms that mathematical models are useful instruments in specifying detailed processes associated with water cycles in the environment and determining the interconnections and mutual relationships between them, as well as quantifying characteristic values for the assessment of quantity and quality of water resources, are a useful instrument. The models provide detailed information on the current and future structure and condition of water resources, including the impact of potential climate changes. Nevertheless, it should be mentioned that criteria for these models, for example use of appropriate data in the correct formats, as well as suitable model calibration is a challenging task, especially in the case of complex models. Future development of the water management sector should concentrate on specific local catchment areas, where application of the integrated water resources management principles and adaptation to climate changes will be more feasible and compatible with local spatial planning. To achieve the aims of the IWRM, a larger number and higher frequency of measurements are needed, in line with the requirements of the Directive 2000/60/EC based on IWRM and documents assessing the degree of its implementation (COM(2012)673 final). In Blueprint (COM (2012) 673 final), the thesis is clearly stressed that the cost of water monitoring is considerably lower than the costs of making incorrect decisions. The spatial scale of works required by the Directive 2000/60/EC focus on river basin areas rather than on individual catchments, where application of principles would be better linked with local spatial planning. At present, research and practice which are developing the concept of water resources management should consider inter alia, local conditions and climate change, to support adaptive water resources management. Adaptive management is defined as a systematic process of improving management by analyzing the effects of implemented water strategies, considering all uncertainties related to forecasts $^{7}$. Therefore, the results of the project also developed conclusions for implementing the concept of adaptive water management in Poland, which can be used in strategic work and sectoral policies. The organizational structure of water resources planning should involve water administration representatives in the process of task implementation to a greater extent, so that their participation is not only limited to specifying and receiving project outcomes, but also includes their opinions ${ }^{8}$. The optimum in this respect would be to achieve such a balance in activities that will provide support for the planning process on the part of scientific units in the form of partial works, whilst also involving representatives of the administration in the formulation of final documents.

\section{REFERENCES}

- 2000/60/EC, Directive of the European Parliament and of the Council of 23 October 2000 establishing a framework for Community action in the field of water policy, Official Journal L 327, 22/12/2000 P. 0001 - 0073, EUR-Lex, Brussels

- ARMA, 2016, Ogłoszenie Nr 1/2018 Prezesa Agencji Restrukturyzacji i Modernizacji Rolnictwa z dnia 21 września 2015 r. w sprawie wielkości średniej powierzchni gruntów rolnych w gospodarstwie rolnym w poszczególnych województwach oraz średniej powierzchni gruntów rolnych w gospodarstwie rolnym w kraju w 2015 roku., available online at https://www.arimr.gov.pl/pomoc-krajowa/ srednia-powierzchnia-gospodarstwa.html (data access 17.01.2020)

- Bartosova A., Capell R., 2017, Baltic Sea Basin under change - impact of climate change on nutrient concentrations, nutrient loads, and river discharges. Baseline and climate change scenarios for the whole BSR, Deliverable 2.5, Project MIRACLE

- COM (2012) 673 final, Communication from the Commission to the European Parliament, the Council, the European Economic and Social Committee and the Committee of the Regions, A Blueprint to Safeguard Europe's Water Resources, EUR-Lex, Brussels

- Czarnecka H., 2005, Atlas podziału hydrograficznego Polski. Part 2: Zestawienia zlewni, IMGW, Warszawa

- Hassing J., Ipsen N., Clausen T.J., Larsen H., Lindgaard-Jørgensen P., 2009, Integrated Water Resources Management in Action. The United Nations World Water Assessment Programme, Dialogue Paper, available online at https://www.gwp.org/globalassets/global/toolbox/references/iwrm-in-action-unescounwwapunep-dhi-2009.pdf (data access 17.01.2020)

- IPCC, 2018, Summary for Policymakers, [in:] Global Warming of $1.5^{\circ} \mathrm{C}$. An IPCC Special
Report on the impacts of global warming of $1.5^{\circ} \mathrm{C}$ above pre-industrial levels and related global greenhouse gas emission pathways, in the context of strengthening the global response to the threat of climate change, sustainable development, and efforts to eradicate poverty, available online at https://www. ipcc.ch/site/assets/uploads/sites/2/2019/05/ SR15_SPM_version_report_LR.pdf (data access 17.01.2020)

- Kondracki J., 2011, Geografia regionalna Polski, Wydawnictwo Naukowe PWN, Warszawa, $468 \mathrm{pp}$.

- Lindström G., Pers C., Rosberg J., Stromqvist J., Arheimer B., 2010, Development and testing of the HYPE (Hydrological Predictions for the Environment) water quality model for different spatial scales, Hydrology Research, 41 (3-4), 295-319, DOI: 10.2166/nh.2010.007

- Miętus M., Filipiak J., Owczarek M., 2004, Klimat wybrzeża południowego Bałtyku. Stan obecny i perspektywy zmian, [in:] Środowisko polskiej strefy południowego Bałtyku - stan obecny i przewidywane zmiany w przededniu integracji europejskiej, J. Cyberski (ed.), Gdańskie Towarzystwo Naukowe, Gdańsk

- PZPWP, 2009, Plan zagospodarowania przestrzennego województwa pomorskiego. Projekt zmiany, Gdańsk, available online at http:// bip.pomorskie.eu/Download/get/id,70623. json (data access 17.01.2020)

- RBMP, 2016, The River basin management plans (2016-2021), available at https://ec.europa.eu/environment/water/participation/ map_mc/countries/poland_en.htm (data access 17.01.2020.

- Staszek W., Kistowski M., 1999, Studium uwarunkowań i kierunków zagospodarowania przestrzennego gminy Wejgerowo, Warszawa-Gdańsk, available online at http://bip. ug.wejherowo.pl/dokumenty/menu/52 (data access 17.01.2020)

- Szalińska W., Otop I., 2012, Ocena struktury czasowo-przestrzennej opadów z wykorzystaniem wybranych wskaźników do identyfikacji zdarzeń ekstremalnych, Woda - Środowiska Obszary Wiejskie, 12 (2), 269-282

- Woś A., 1993, regiony klimatyczne Polski w świetle częstości występowania różnych typów pogody, Zeszyty Instytutu Geografii i Przestrzennego Zagospodarowania PAN, 20, $91 \mathrm{pp}$. 

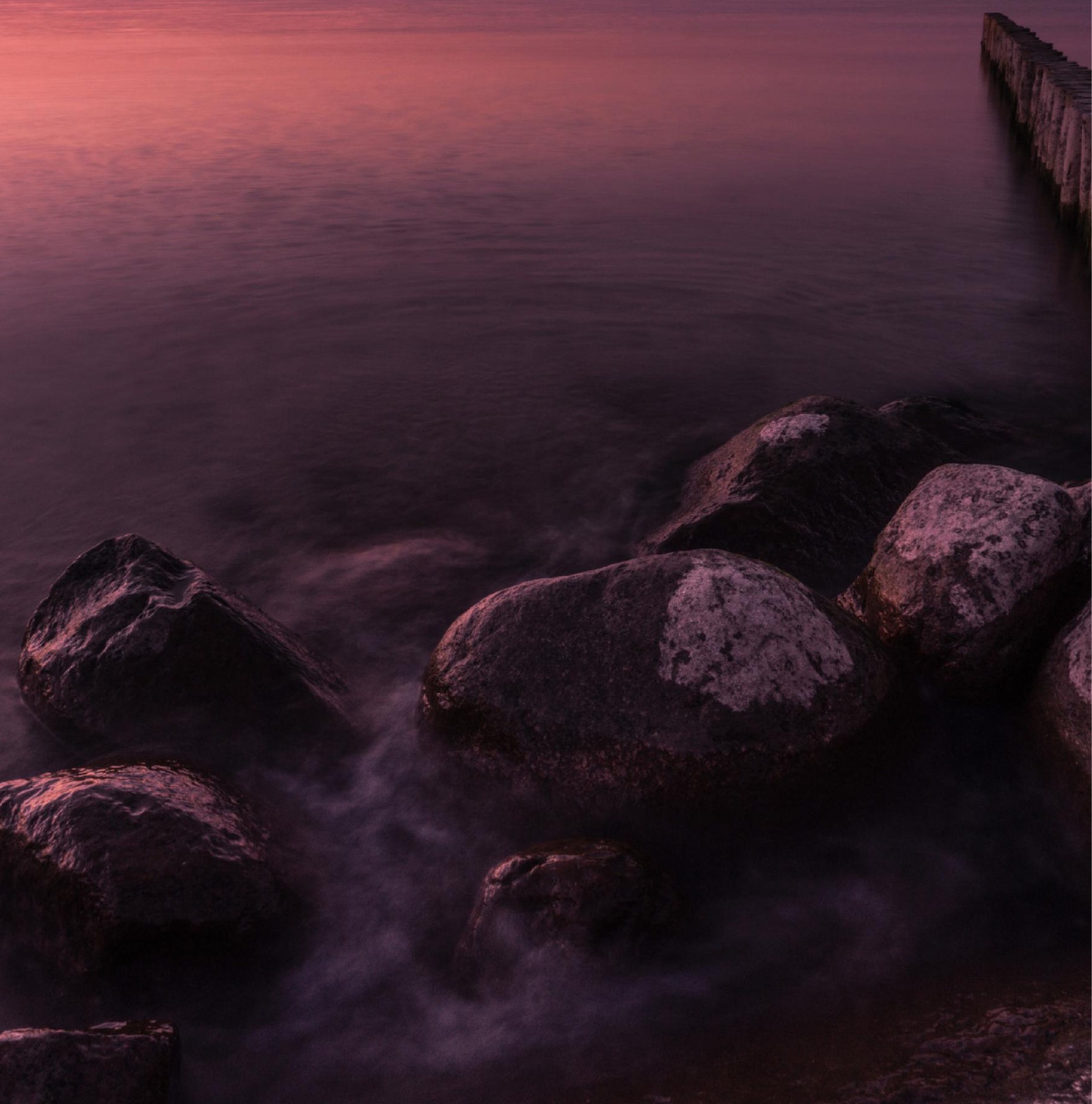